\title{
Relationship between Motivational Practices and Organisational Citizenship Behaviour with Special Reference to Employees of Manufacturing Industries in Coimbatore District
}

\author{
Lydia H Swamy
}

\begin{abstract}
This paper reports on the findings of a research to investigate the relationship between Motivational practices and Organisational Citizenship Behaviour of employees working in select manufacturing industries in Coimbatore District. The findings of the study highlight the importance of motivational practices to enhance employee effectiveness.
\end{abstract}

Index Terms: Motivational practices, Organisational Citizenship Behaviour.

\section{INTRODUCTION}

In today's rapidly changing corporate environment, organizations want to use maximum potential of their human resources to stay ahead of the fierce competition and survive. Great organizations are built on the inherent values of their human resources, as motivated and committed employees almost always allow an organization to grow faster than similar competitive organizations. Well motivated and committed workforces feel that organizations value them and they play an essential role within their organization which significantly enhances both employees' as well as organizational performance ${ }^{1}$. Motivated and committed employees with high levels of job involvement are considered as an important asset to an organization. Keeping the employee motivated, committed with high job involvement are always rewarding to a business as motivated and committed employees are more productive and higher productivity usually results in higher profits ${ }^{2}$.

In a manufacturing industry such as automobile, pump, textile, engineering and sugar industries, employees who are highly motivated and committed to the organization provide excellent quality of services keeping the customer happy and satisfied which is always positive for a business. Employees

Revised Manuscript Received on July 08, 2019.

First Author Name* his/her department, Name of the affiliated College or University/Industry, City, Country. Email: xyz1 @ blueeyesintlligence.org

Second Author Name, department, Name of the affiliated College or University/Industry, City, Country. Email: xyz2@blueeyesintlligence.org

Third Author Name, department, Name of the affiliated College or University/Industry, City, Country. Email: xyz3@ blueeyesintlligence.org with high job involvement are more focused towards their jobs $^{3}$, likely to have less turnover and leaving .

intensions, ${ }^{4}$ and are motivated to stay with the organization $^{5}$. They grow in expertise and thus become even more valuable to their employer and the organization. Importance of motivation, commitment and job involvement in the workplace is obvious as well motivated and committed employees with high levels of job involvement affect both their own as well as organizational outcomes ${ }^{6}$.

In this paper an attempt has been made to identify the influence of motivational practices. For this purpose, a field survey method was employed to collect first hand information from 720 employees working in various manufacturing industries consisting of automobile, textile, pump, sugar and engineering. The sample respondents were selected from various geographical locations and industries of Coimbatore district.

The motivational practices have been categorized into 10 heads viz., safety and security, provision of welfare measures, monetary benefits, promotion and transfer, work efficiency, employee interpersonal relationship, social relationship, grievance handling procedures, training and development and performance management system and OCB has been classified into 3 heads viz., job satisfaction, organizational commitment and employee performance.

\section{DEGREE OF ASSOCIATION BETWEEN MOTIVATIONAL PRACTICES AND OCB - CORRELATION ANALYSIS}

Correlation analysis was applied to identify the degree of relationship between the independent variables which include Safety \& Security, Provision of Welfare Measures, Monetary Benefits, Promotion \& Transfer, Work Efficiency, Employee Interpersonal Relationship, Social Relationship, 
Relationship between Motivational Practices and Organisational Citizenship Behaviour with special reference to employees of manufacturing industries in Coimbatore District

Grievance Handling Procedures, Training and Development and Performance Management System and the dependent variables job satisfaction, organizational commitment and employee performance.

TABLE 1

DEGREE OF ASSOCIATION BETWEEN MOTIVATIONAL PRACTICES AND OCB

\begin{tabular}{|c|c|c|c|c|}
\hline о & $\begin{array}{l}\text { Motivational } \\
\text { Factors }\end{array}$ & $\begin{array}{l}\text { Job } \\
\text { Satisfact } \\
\text { ion }\end{array}$ & $\begin{array}{l}\text { Organizatio } \\
\text { nal } \\
\text { Commitmen } \\
\text { t }\end{array}$ & $\begin{array}{l}\text { Employe } \\
\text { e } \\
\text { Perform } \\
\text { ance }\end{array}$ \\
\hline & $\begin{array}{r}\text { Safety } \quad \& \\
\text { Security }\end{array}$ & $\begin{array}{r}0.600 * \\
*\end{array}$ & $0.585 * *$ & $\begin{array}{r}0.613 * \\
*\end{array}$ \\
\hline & $\begin{array}{l}\text { Provision of } \\
\text { Welfare } \\
\text { Measures }\end{array}$ & * $0.557 *$ & $0.551 * *$ & * $0.522 *$ \\
\hline & $\begin{array}{l}\text { Monetary } \\
\text { Benefits }\end{array}$ & $\begin{array}{r}0.727 * \\
*\end{array}$ & $0.751 * *$ & $\begin{array}{r}0.655^{*} \\
*\end{array}$ \\
\hline & $\begin{array}{l}\text { Promotion } \\
\text { \& Transfer }\end{array}$ & * $0.662 *$ & $0.684 * *$ & $\begin{array}{r}0.663 * \\
*\end{array}$ \\
\hline & $\begin{array}{c}\text { Work } \\
\text { Efficiency }\end{array}$ & * $0.614 *$ & $0.581 * *$ & $\begin{array}{r}0.641 * \\
*\end{array}$ \\
\hline & \begin{tabular}{l}
\multicolumn{1}{c}{ Employee } \\
Interpersonal \\
Relationship
\end{tabular} & * $0.605 *$ & $0.591 * *$ & $\begin{array}{r}0.663^{*} \\
*\end{array}$ \\
\hline & $\begin{array}{c}\text { Social } \\
\text { Relationship }\end{array}$ & $\begin{array}{r}0.563 * \\
*\end{array}$ & $0.530 * *$ & $\begin{array}{r}0.467 * \\
*\end{array}$ \\
\hline & \begin{tabular}{l}
\multicolumn{1}{c}{ Grievance } \\
Handling \\
Procedures
\end{tabular} & ${ }^{*} 0.704 *$ & $0.700 * *$ & $\begin{array}{r}0.680^{*} \\
*\end{array}$ \\
\hline & $\begin{array}{l}\text { Training } \\
\text { and } \\
\text { Development }\end{array}$ & * $0.672 *$ & $0.677 * *$ & $\begin{array}{r}0.678 * \\
*\end{array}$ \\
\hline 0 & $\begin{array}{l}\text { Performanc } \\
\text { e Management } \\
\text { System }\end{array}$ & * $0.687 *$ & $0.729 * *$ & $\begin{array}{r}0.725 * \\
*\end{array}$ \\
\hline
\end{tabular}

Note : ** - Significant at $1 \%$ level

It could be noted from the above analysis that all the motivational practices had a high positive significant association with job satisfaction, organizational commitment and employee performance. It indicates that when motivational practices increase among the employees their job satisfaction, organizational commitment and their performance also increase, thus implying a direct relationship between the motivational practices and OCB.

RELATIONSHIP BETWEEN MOTIVATIONAL FACTORS AND ORGANIZATIONAL CITIZENSHIP BEHAVIOUR - MULTIPLE REGRESSION ANALYSIS

\section{MOTIVATIONAL PRACTICES AND JOB SATISFACTION}

In the following analysis, the interdependence of ten selected motivational practices and the latent variable employee satisfaction is discerned. The details of the analysis are formulated in the table 2 .

TABLE 2

MOTIVATIONAL PRACTICES AND JOB SATISFACTION

\begin{tabular}{|c|c|c|c|c|c|}
\hline \multirow[t]{2}{*}{$\begin{array}{l}\mathbf{S} \\
\mathbf{N} \\
\mathbf{0}\end{array}$} & \multirow[t]{2}{*}{ Variables } & \multicolumn{2}{|c|}{$\begin{array}{l}\text { Unstandar } \\
\text { dised } \\
\text { coefficients }\end{array}$} & \multirow[t]{2}{*}{$\mathbf{t}$} & \multirow[t]{2}{*}{. } \\
\hline & & B & SE & & \\
\hline & Constant & $18^{0.1}$ & $18^{0.1}$ & & \\
\hline 1 & $\begin{array}{r}\text { Safety } \quad \& \\
\text { Security }\end{array}$ & $04^{0.0}$ & $33^{0.0}$ & $\begin{array}{l}0 \\
.12 \\
9\end{array}$ & $\begin{array}{l}0.8 \\
98^{\mathrm{NS}}\end{array}$ \\
\hline 2 & $\begin{array}{l}\text { Provision of } \\
\text { Welfare } \\
\text { Measures }\end{array}$ & $\begin{array}{c}-0 . \\
028\end{array}$ & $34^{0.0}$ & $\begin{array}{l}- \\
0.8 \\
12 \\
\end{array}$ & $\begin{array}{l}0.4 \\
17^{\mathrm{NS}}\end{array}$ \\
\hline 3 & $\begin{array}{l}\text { Monetary } \\
\text { Benefits }\end{array}$ & $10^{0.2}$ & $30^{0.0}$ & $\begin{array}{l}6 \\
.99 \\
3\end{array}$ & $\begin{array}{r}0.0 \\
00 * *\end{array}$ \\
\hline 4 & $\begin{array}{l}\text { Promotion \& } \\
\text { Transfer }\end{array}$ & $50^{0.0}$ & $31^{0.0}$ & $\begin{array}{l}1 \\
.63 \\
3\end{array}$ & $03^{\mathrm{NS}}$ \\
\hline 5 & $\begin{array}{c}\text { Work } \\
\text { Efficiency }\end{array}$ & $63^{0.1}$ & $37^{0.0}$ & $\begin{array}{l}4 \\
.44 \\
6\end{array}$ & $\begin{array}{r}0.0 \\
00 * *\end{array}$ \\
\hline 6 & \begin{tabular}{l}
\multicolumn{1}{c}{ Employee } \\
Interpersonal \\
Relationship
\end{tabular} & $64^{0.0}$ & $42^{0.0}$ & $\begin{array}{l}1 \\
.52 \\
2\end{array}$ & $28^{0.1}$ \\
\hline 7 & $\begin{array}{c}\text { Social } \\
\text { Relationship }\end{array}$ & $10^{0.1}$ & $21^{0.0}$ & $\begin{array}{r}5 \\
.18 \\
4\end{array}$ & $\begin{array}{r}0.0 \\
00 * *\end{array}$ \\
\hline 8 & $\begin{array}{l}\quad \text { Grievance } \\
\text { Handling } \\
\text { Procedures } \\
\end{array}$ & $71^{0.1}$ & $38^{0.0}$ & $\begin{array}{l}\quad 4 \\
.48 \\
7 \\
\end{array}$ & $\begin{array}{r}0.0 \\
00 * *\end{array}$ \\
\hline 9 & $\begin{array}{l}\text { Training and } \\
\text { Development }\end{array}$ & $83^{0.0}$ & $30^{0.0}$ & $\begin{array}{l}2 \\
.79 \\
3\end{array}$ & $\begin{array}{r}0.0 \\
05 * *\end{array}$ \\
\hline 0 & $\begin{array}{l}\text { Performance } \\
\text { Management } \\
\text { System }\end{array}$ & $29^{0.1}$ & $30^{0.0}$ & $\begin{array}{l}4 \\
.27 \\
4\end{array}$ & $\begin{array}{r}0.0 \\
00 * *\end{array}$ \\
\hline & $\mathbf{R}^{2}$ value & \multicolumn{3}{|c|}{$\mathbf{0 . 8 8 3}$} & \\
\hline & F value & \multicolumn{3}{|c|}{156.076} & \\
\hline & 'p' value & \multicolumn{3}{|c|}{$0.000 * *$} & \\
\hline
\end{tabular}

Note: $* *$ - Significant at $1 \%$ level; NS - Not significant

The multiple linear regression co-efficient (dependent variable) is found to be a statistically good fit as $\mathrm{R}^{2}$ is 0.883 . It shows that independent variables contribute about $88.3 \%$ of the variation in the job satisfaction felt by the selected respondents and this is statistically significant at $1 \%$.

The resultant equation is 


\section{Job Satisfaction}

$=0.118+0.004$ (Safety \& Security) -0.028 (Provision of Welfare Measures) +0.210 (Monetary Benefits) +0.050

(Promotion \& Transfer) +0.163 (Work Efficiency) +0.064 (Employee Interpersonal Relationship) +0.110 (Social Relationship) + 0.171 (Grievance Handling Procedures) + 0.083 (Training and Development) + 0.129 (Performance Management System)

It is found from the analysis that the motivational factors safety \& security, provision of welfare measures, promotion $\&$ transfer and employee interpersonal relationship have no association with job satisfaction and thus the variables are not influence the job satisfaction of the employees. All the remaining six motivation variables have strong positive association with the job satisfaction. Of the six variables, 'monetary benefits' is the most influencing factor than the other five variables and thus it indicates that the changes in monetary benefits will affect the job satisfaction of the employees.

\section{MOTIVATIONAL PRACTICES AND ORGANIZATIONAL COMMITMENT}

In the following analysis, the interdependence of ten selected motivational practices and a latent variable organizational commitment is discerned. The details of the analysis are formulated in the table 3 .

TABLE 3

MOTIVATIONAL PRACTICES

AND ORGANIZATIONAL COMMITMENT

\begin{tabular}{|c|c|c|c|c|c|}
\hline \multirow{2}{*}{ 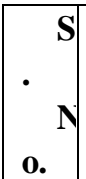 } & \multirow{2}{*}{ Variables } & \multicolumn{2}{|c|}{$\begin{array}{l}\text { Unstandardise } \\
\text { d coefficients }\end{array}$} & \multirow{2}{*}{ t } & \multirow{2}{*}{. ${ }^{\text {Sig }}$} \\
\hline & & B & SE & & \\
\hline & Constant & $1^{0.28}$ & $4^{0.11}$ & & \\
\hline 1 & $\begin{array}{r}\text { Safety \& } \\
\text { Security }\end{array}$ & $1^{-0.01}$ & $2^{0.03}$ & $\begin{array}{l}- \\
0.3 \\
47\end{array}$ & $\begin{array}{c}0.7 \\
29^{\mathrm{NS}}\end{array}$ \\
\hline 2 & \begin{tabular}{l}
\multicolumn{1}{c}{ Provision of } \\
Welfare \\
Measures
\end{tabular} & $2^{-0.05}$ & $3^{0.03}$ & $\begin{array}{l}- \\
1.5 \\
90\end{array}$ & $\begin{array}{c}0.1 \\
12^{\mathrm{NS}}\end{array}$ \\
\hline 3 & $\begin{array}{l}\text { Monetary } \\
\text { Benefits }\end{array}$ & $5^{0.24}$ & $9^{0.02}$ & $\begin{array}{l}8 \\
.45 \\
1\end{array}$ & $\begin{array}{r}0.0 \\
00^{* *}\end{array}$ \\
\hline 4 & $\begin{array}{l}\text { Promotion } \\
\text { \& Transfer }\end{array}$ & $3^{0.06}$ & $0^{0.03}$ & $\begin{array}{l}2 \\
.12 \\
8\end{array}$ & $\begin{array}{r}0.0 \\
34 *\end{array}$ \\
\hline 5 & $\begin{array}{c}\text { Work } \\
\text { Efficiency }\end{array}$ & $0^{0.10}$ & $5^{0.03}$ & $\begin{array}{l}2 \\
.84 \\
1\end{array}$ & $\begin{array}{r}0.0 \\
05^{* *}\end{array}$ \\
\hline 6 & $\begin{array}{c}\text { Employee } \\
\text { Interpersonal } \\
\text { Relationship }\end{array}$ & $5^{0.05}$ & $1^{0.04}$ & $\begin{array}{l}1 \\
.34 \\
4\end{array}$ & $\begin{array}{c}0.1 \\
79^{\mathrm{NS}}\end{array}$ \\
\hline 7 & Social & 0.07 & 0.02 & 3 & 0.0 \\
\hline
\end{tabular}

\begin{tabular}{|c|c|c|c|c|c|}
\hline & Relationship & 2 & 1 & $\begin{array}{l}.49 \\
7\end{array}$ & $01 * *$ \\
\hline 8 & $\begin{array}{l}\quad \text { Grievance } \\
\text { Handling } \\
\text { Procedures }\end{array}$ & $0^{0.17}$ & $7^{0.03}$ & $\begin{array}{l}4 \\
.63 \\
6\end{array}$ & $\begin{array}{r}0.0 \\
00^{* *}\end{array}$ \\
\hline 9 & $\begin{array}{l}\text { Training } \\
\text { and } \\
\text { Development }\end{array}$ & $2^{0.06}$ & $9^{0.02}$ & $\begin{array}{l}2 \\
.15 \\
5\end{array}$ & $\begin{array}{r}0.0 \\
31 *\end{array}$ \\
\hline $0^{1}$ & $\begin{array}{l}\text { Performanc } \\
\text { e } \\
\text { Management } \\
\text { System }\end{array}$ & $6^{0.20}$ & $9^{0.02}$ & $\begin{array}{l}7 \\
.06 \\
3\end{array}$ & $\begin{array}{r}0.0 \\
00^{* *}\end{array}$ \\
\hline & $\mathbf{R}^{2}$ value & \multicolumn{3}{|c|}{0.804} & \\
\hline & F value & \multicolumn{3}{|c|}{168.925} & \\
\hline & 'p' value & \multicolumn{3}{|c|}{$0.000 * *$} & \\
\hline
\end{tabular}

Note: $* *$ - Significant at $1 \%$ level; NS - Not significant

The multiple linear regression co-efficient (dependent variable) is found to be a statistically good fit as $\mathrm{R}^{2}$ is 0.804 . It shows that independent variables contribute about $80.4 \%$ of the variation in the organizational commitment felt by the selected sample respondents and this is statistically significant at $1 \%$ and $5 \%$ respectively.

The resultant equation is

\section{Organisational Commitment}

$=0.281-0.011$ (Safety \& Security) -0.052 (Provision of Welfare Measures) +0.245 (Monetary Benefits) +0.063 (Promotion \& Transfer) +0.100 (Work Efficiency) +0.055 (Employee Interpersonal Relationship) + 0.072 (Social Relationship) +0.170 (Grievance Handling Procedures) + 0.062 (Training and Development) + 0.206 (Performance Management System)

It is found from the analysis that the motivational factors safety \& security, provision of welfare measures and employee interpersonal relationship have no association with organsational commitment and thus the variables are not influence organsational in monetary benefits will affect the organizational commitment of the employees. commitment. All the remaining seven motivation variables have strong positive association with the organizational commitment. Of the seven variables, 'monetary benefits' has the highest influencing factor than the other six variables and thus it indicates that the changes

\section{MOTIVATIONAL PRACTICES AND EMPLOYEE PERFORMANCE}

In the following analysis, the interdependence of ten selected motivational practices and a latent variable employee performance is discerned. The details of the analysis are formulated in the table 4.

\section{TABLE 4}

MOTIVATIONAL PRACTICES AND EMPLOYEE PERFORMANCE 
Relationship between Motivational Practices and Organisational Citizenship Behaviour with special reference to employees of manufacturing industries in Coimbatore District

\begin{tabular}{|c|c|c|c|c|c|}
\hline \multirow{2}{*}{  } & \multirow[t]{2}{*}{ Variables } & \multicolumn{2}{|c|}{$\begin{array}{l}\text { Unstanda } \\
\text { rdised } \\
\text { coefficients }\end{array}$} & \multirow[t]{2}{*}{$\mathbf{t}$} & \multirow[t]{2}{*}{ Sig. } \\
\hline & & B & SE & & \\
\hline & Constant & $\begin{array}{l}0 \\
.33 \\
6\end{array}$ & $09^{0.1}$ & & \\
\hline 1 & $\begin{array}{r}\text { Safety \& } \\
\text { Security }\end{array}$ & $\begin{array}{l}0 \\
.07 \\
7\end{array}$ & 31 & $\begin{array}{l}2 \\
.50 \\
3\end{array}$ & $3^{0.01}$ \\
\hline 2 & $\begin{array}{l}\text { Provision of } \\
\text { Welfare } \\
\text { Measures }\end{array}$ & $\begin{array}{l}- \\
0.0 \\
80\end{array}$ & $31^{0.0}$ & $\begin{array}{l}- \\
2.5 \\
63\end{array}$ & $1^{0.01}$ \\
\hline 3 & $\begin{array}{l}\text { Monetary } \\
\text { Benefits }\end{array}$ & $\begin{array}{l}\quad 0 \\
.04 \\
7 \\
\end{array}$ & $28^{0.0}$ & $\begin{array}{l}1 \\
.68 \\
8 \\
\end{array}$ & $\begin{array}{l}0.09 \\
2^{\mathrm{NS}}\end{array}$ \\
\hline 4 & $\begin{array}{l}\text { Promotion } \\
\text { \& Transfer }\end{array}$ & $\begin{array}{l}\quad 0 \\
.06 \\
9 \\
\end{array}$ & $28^{0.0}$ & $\begin{array}{l}2 \\
.44 \\
5 \\
\end{array}$ & $5^{0.01}$ \\
\hline 5 & $\begin{array}{c}\text { Work } \\
\text { Efficiency }\end{array}$ & $\begin{array}{l}\quad 0 \\
.18 \\
4 \\
\end{array}$ & $34^{0.0}$ & $\begin{array}{l}5 \\
.44 \\
3 \\
\end{array}$ & $\begin{array}{l}0.00 \\
0^{* *} \\
\end{array}$ \\
\hline 6 & \begin{tabular}{l}
\multicolumn{1}{c}{ Employee } \\
Interpersonal \\
Relationship
\end{tabular} & $\begin{array}{l}\quad 0 \\
.17 \\
4\end{array}$ & $39^{0.0}$ & $\begin{array}{l}4 \\
.47 \\
8\end{array}$ & $\begin{array}{l}0.00 \\
0^{* *}\end{array}$ \\
\hline 7 & $\begin{array}{c}\text { Social } \\
\text { Relationship }\end{array}$ & $\begin{array}{l}\quad 0 \\
.00 \\
5 \\
\end{array}$ & $20^{0.0}$ & $\begin{array}{l}\quad 0 \\
.23 \\
8 \\
\end{array}$ & $\begin{array}{l}0.81 \\
2^{\mathrm{NS}}\end{array}$ \\
\hline 8 & $\begin{array}{l}\text { Grievance } \\
\text { Handling } \\
\text { Procedures }\end{array}$ & $\begin{array}{l}\quad 0 \\
.11 \\
1 \\
\end{array}$ & $35^{0.0}$ & $\begin{array}{r}3 \\
.16 \\
8 \\
\end{array}$ & $\begin{array}{l}0.00 \\
2^{* *} \\
\end{array}$ \\
\hline 9 & $\begin{array}{l}\text { Training } \\
\text { and } \\
\text { Development }\end{array}$ & $\begin{array}{l}\quad 0 \\
.09 \\
3\end{array}$ & $27^{0.0}$ & $\begin{array}{l}3 \\
.39 \\
7\end{array}$ & $\begin{array}{l}0.00 \\
1 * *\end{array}$ \\
\hline $0^{1}$ & $\begin{array}{l}\text { Performanc } \\
\text { e } \\
\text { Management } \\
\text { System } \\
\end{array}$ & $\begin{array}{l}\quad 0 \\
.24 \\
0 \\
\end{array}$ & $28^{0.0}$ & $\begin{array}{r}8 \\
.60 \\
7 \\
\end{array}$ & $\begin{array}{l}0.00 \\
0 * *\end{array}$ \\
\hline & $\mathbf{R}^{2}$ value & & & & \\
\hline & F value & & .515 & & \\
\hline & 'p' value & & $00 * *$ & & \\
\hline
\end{tabular}

Note: $* *$ - Significant at $1 \%$ level; NS - Not significant

The multiple linear regression co-efficient (dependent variable) is found to be statistically good fit as $\mathrm{R}^{2}$ is 0.887 . It shows that independent variables contribute about $88.7 \%$ of the variation in the employee performance and this is statistically significant at $1 \%$ and $5 \%$ respectively.

The resultant equation is

\section{Employee Performance}

$=0.336+0.077$ (Safety \& Security) -0.080 (Provision of Welfare Measures) +0.047 (Monetary Benefits) +0.069 (Promotion \& Transfer) +0.184 (Work Efficiency) +0.174 (Employee Interpersonal Relationship) + 0.005 (Social Relationship) + 0.111 (Grievance Handling Procedures) + 0.093 (Training and Development) + 0.240 (Performance Management System)

It is found from the analysis that the motivational factors monetary benefits and social relationship have no association with employee performance and thus the variables do not influencing the employees' performance. Rest of eight influencing factors of motivation, the variable 'Provision of welfare measures' have negative association at 5 percent level with employee performance. Of the eight variables, 'Performance management system' is the most influencing factor than the other seven variables and thus it indicates that the changes in performance management system in the manufacturing companies will affect the employee performance.

\section{RELATIONSHIP BETWEEN MOTIVATIONAL PRACTICES, MOTIVATION AND OCB - STRUCTURAL EQUATION MODELLING}

Research model and hypothesis formulation

An attempt was made to find out the relationship between the motivational practices, motivation and three variables of OCB among the selected sample respondents whose are working in manufacturing industries in Coimbatore district. For this purpose, ten manifest variables are selected and the latent variables are presented in the Table 5.

TABLE 5

MANIFEST VARIABLES AND LATENT VARIABLES

\begin{tabular}{|c|c|c|}
\hline No. & Manifest Variables & Latent Variables \\
\hline 1 & Safety and Security & \multirow{10}{*}{$\begin{array}{l}\text { 1. Motivation } \\
\text { 2. Employee } \\
\text { satisfaction } \\
\text { 3. Organizational } \\
\text { commitment } \\
\text { 4. Employee } \\
\text { performance }\end{array}$} \\
\hline 2 & Provision of Welfare measures & \\
\hline 3 & Monetary benefits & \\
\hline 4 & Promotion and Transfer & \\
\hline 5 & Work efficiency & \\
\hline 6 & $\begin{array}{ll}\text { Employee } & \text { Interpersonal } \\
\text { Relationship } & \end{array}$ & \\
\hline 7 & Social Relationship & \\
\hline 8 & Grievance Handling procedures & \\
\hline 9 & Training and Development & \\
\hline 10 & $\begin{array}{l}\text { Performance } \quad \text { Management } \\
\text { system }\end{array}$ & \\
\hline
\end{tabular}

The research hypotheses have been defined on the basis of the factors influencing motivation and OCB of employees in manufacturing industries in Coimbatore district.

$\mathrm{H}_{1}$ : There is no significant association between safety and security, provision of welfare measures, monetary benefits, promotion and transfer, work efficiency, employee interpersonal relationship, social relationship, grievance handling procedures, training and development and performance management system and motivation.

$\mathrm{H}_{2}$ : There is no significant association between motivation and job satisfaction.

$\mathrm{H}_{3}$ : There is no significant association between motivation and organizational commitment.

$\mathrm{H}_{4}$ : There is no significant association between motivation and employee performance.

To test the hypothesis Structural Equation Model was used and the output in the form of path diagram is given below

equations with commas or periods when they are part of a sentence, as in:

$$
a+b=\gamma
$$




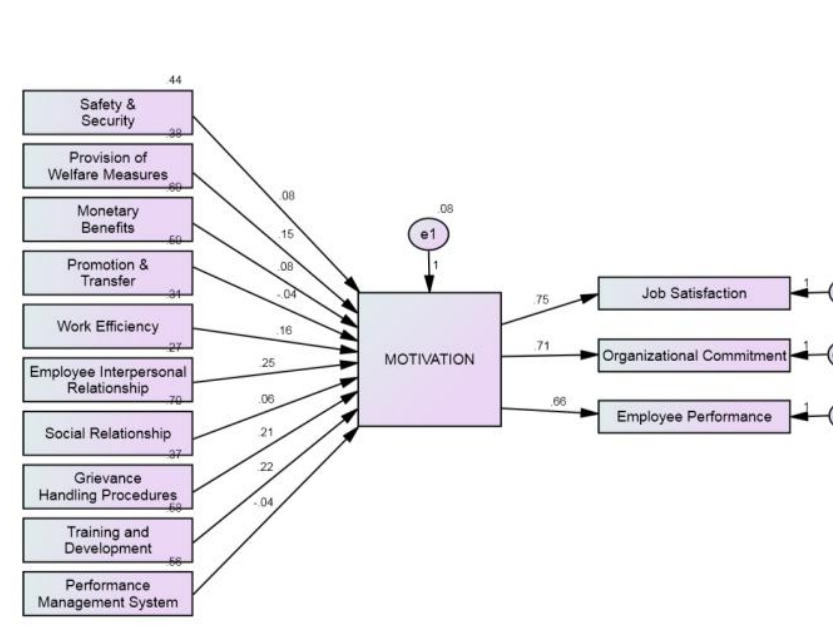

\begin{tabular}{|l|l|l|l|}
\hline & approximation) & $\begin{array}{l}\text { close fit of } \\
\text { the model }\end{array}$ \\
\hline
\end{tabular}

The Table 6 indicates that the model fit indices of factors influencing motivation and OCB among the employee in manufacturing industry in Coimbatore district. The Goodness of fit index (GFI) score is 0.976 , adjusted goodness (3) 0 fit index (AGFI) score is 0.952, comparative fit index (CFI) score is 0.903 , normed fit index (NFI) score is 0.931 , Tucker Lewis index (TLI) score is 0.926 . The Root Mean Squared Error of Approximation (RMSEA) secured 0.033 that indicates that the model is a good fit with a reasonable error of approximation. The following table shows the regression weights among the manifest and latent variables.

directional effects are regression coefficients. The regression coefficients and correlations measure the strength of the relations between the variables. The regression coefficients of promotion \& transfer and performance management system shows negative association with the motivation and the variable employee interpersonal relationship has the highest association with motivation among the sample respondents. On the other hand, the variable social relationship has the least significant association with the motivation.

Motivation has a good association with the OCB variables viz., job satisfaction, organizational commitment and employee performance.

The researcher applied model fit indices to decide whether to accept the model or to fine tune the model further. The result of model fit test is presented in the Table 6 .

TABLE 6

MODEL FIT INDICES OF SELECTED FACTORS INFLUENCING MOTIVATION AND OCB

\begin{tabular}{|c|c|c|c|}
\hline o. & Test Factor & $\begin{array}{r}\begin{array}{r}\text { Calcula } \\
\text { ted Value }\end{array} \\
\end{array}$ & $\begin{array}{l}\text { Accepta } \\
\text { ble Value }\end{array}$ \\
\hline 1 & $\begin{array}{l}\quad \text { GFI } \\
\text { (Goodness-of-fit } \\
\text { index) }\end{array}$ & 0.976 & \multirow{5}{*}{$\begin{array}{l}\quad>=0.90 \\
\text { and above } \\
\text { satisfact } \\
\text { ory fit } \\
0.80 \text { to } \\
<0.9 \\
\text { acceptab } \\
\text { le fit } \\
\text { (Hair et } \\
\text { al. 2006) }\end{array}$} \\
\hline 2 & \begin{tabular}{l}
\multicolumn{1}{c}{ AGFI } \\
(Adjusted \\
goodness-of-fit \\
index)
\end{tabular} & 0.952 & \\
\hline 3 & $\begin{array}{l}\text { CFI } \\
\text { (Comparative fit } \\
\text { index) }\end{array}$ & 0.903 & \\
\hline 4 & $\begin{array}{l}\text { NFI (Normed } \\
\text { fit index) }\end{array}$ & 0.931 & \\
\hline 5 & $\begin{array}{l}\quad \text { TLI } \\
\text { (Tucker-Lewis } \\
\text { index) }\end{array}$ & 0.926 & \\
\hline 6 & \begin{tabular}{l}
\multicolumn{2}{c}{ RMSEA } \\
(Root mean \\
square error of
\end{tabular} & 0.033 & $\begin{array}{l}0.05 \text { or } \\
\text { less would } \\
\text { indicate a }\end{array}$ \\
\hline
\end{tabular}

\section{TABLE 7}

\section{REGRESSION WEIGHTS FOR FACTORS INFLUENCING MOTIVATION AND OCB OF EMPLOYEES}

\begin{tabular}{|c|c|c|c|c|c|c|}
\hline $\begin{array}{c}\text { Latent } \\
\text { Variable }\end{array}$ & & $\begin{array}{r}\text { Measur } \\
\text { ed Variable }\end{array}$ & $\begin{array}{l}\text { Esti } \\
\text { mate }\end{array}$ & $\begin{array}{ll} & \text { S. } \\
\text { E. } & \end{array}$ & $\begin{array}{ll} & \text { C. } \\
\text { R. } & \\
\end{array}$ & $\begin{array}{l}\text { 'p' } \\
\text { value }\end{array}$ \\
\hline Motivation & $\leftarrow$ & $\begin{array}{c}\text { Safety } \\
\text { and Security }\end{array}$ & 0.079 & $15^{0.0}$ & $82^{5.0}$ & $\begin{array}{c}0.0 \\
00^{* * *} \\
\end{array}$ \\
\hline Motivation & $\leftarrow$ & $\begin{array}{l}\quad \text { Provisio } \\
\mathrm{n} \text { of Welfare } \\
\text { measures }\end{array}$ & 0.154 & $17^{0.0}$ & $58^{9.2}$ & $00^{0.0}$ \\
\hline Motivation & $\leftarrow$ & $\begin{array}{c}\text { Monetar } \\
\text { y benefits }\end{array}$ & 0.081 & $12^{0.0}$ & $4^{6.5}$ & $\begin{array}{r}0.0 \\
00^{* * *}\end{array}$ \\
\hline Motivation & $\leftarrow$ & \begin{tabular}{l}
\multicolumn{2}{c}{ Promoti } \\
on and \\
Transfer
\end{tabular} & $2^{-0.04}$ & $13^{0.0}$ & $193^{-3 .}$ & $01^{0.0}$ \\
\hline Motivation & $\leftarrow$ & $\begin{array}{r}\text { Work } \\
\text { efficiency }\end{array}$ & 0.164 & $18^{0.0}$ & $69^{8.9}$ & $\begin{array}{c}0.0 \\
00^{* * *}\end{array}$ \\
\hline Motivation & $\leftarrow$ & $\begin{array}{l}\quad \text { Employe } \\
\text { e } \\
\text { Interpersonal } \\
\text { Relationship }\end{array}$ & 0.253 & $20^{0.0}$ & $765^{12 .}$ & $00^{0 * 0}$ \\
\hline Motivation & $\leftarrow$ & $\begin{array}{c}\text { Social } \\
\text { Relationship }\end{array}$ & 0.063 & $12^{0.0}$ & $588^{5.1}$ & $\begin{array}{r}0.0 \\
00^{* * *} \\
\end{array}$ \\
\hline Motivation & $\leftarrow$ & $\begin{array}{l}\text { Grievanc } \\
\text { e Handling } \\
\text { procedures }\end{array}$ & 0.210 & $17^{0.0}$ & $452^{12 .}$ & $\begin{array}{c}0.0 \\
00^{* *}\end{array}$ \\
\hline Motivation & $\leftarrow$ & $\begin{array}{l}\text { Training } \\
\text { and } \\
\text { Development }\end{array}$ & 0.216 & $13^{0.0}$ & $143^{16 .}$ & $00^{0 * 0}$ \\
\hline Motivation & $\leftarrow$ & \begin{tabular}{l}
\multicolumn{1}{c}{ Performa } \\
nce \\
Management \\
system
\end{tabular} & $3^{-0.04}$ & $14^{0.0}$ & $146^{-3 .}$ & $\begin{array}{c}0.0 \\
02 * *\end{array}$ \\
\hline $\begin{array}{c}\text { Job } \\
\text { Satisfaction } \\
\end{array}$ & $\leftarrow$ & $\begin{array}{l}\text { Motivati } \\
\text { on }\end{array}$ & 0.750 & $42^{0.0}$ & $884^{17 .}$ & $\begin{array}{c}0.0 \\
00^{* * *} \\
\end{array}$ \\
\hline $\begin{array}{l}\text { Organizati } \\
\text { onal } \\
\text { Commitment }\end{array}$ & $\leftarrow$ & $\begin{array}{l}\text { Motivati } \\
\text { on }\end{array}$ & 0.706 & $44^{0.0}$ & $139^{16 .}$ & $00^{0.0}$ \\
\hline $\begin{array}{l}\text { Employee } \\
\text { Performance }\end{array}$ & $\leftarrow$ & $\begin{array}{l}\text { Motivati } \\
\text { on }\end{array}$ & 0.657 & $41^{0.0}$ & $223^{16 .}$ & $\begin{array}{r}0.0 \\
00^{* * *}\end{array}$ \\
\hline
\end{tabular}

Note : ** - Significant at $1 \%$ level; * - Significant at 5\% level;

\section{NS - Not Significant}

From the analysis, it is inferred that all the motivational factors have significant association with motivation. It is found from the analysis that the all null hypothesis is rejected and so there is a significant association between the motivational practices and level of motivation. On the other hand, the motivation also has significant association with job satisfaction, organizational commitment and employee performance. 
Relationship between Motivational Practices and Organisational Citizenship Behaviour with special reference to employees of manufacturing industries in Coimbatore District

Among the selected ten measured variables, employee interpersonal relationship is highly influencing motivation factor followed by training \& development and grievance handling procedure. Hence, the manufacturing companies can plan to enhance the motivational practices among the employees to increase the level of motivation and ensure job satisfaction, organizational commitment and performance.

\section{SUGGESTIONS}

Even though the companies following various types of motivation practices to keep their employee's motivated.

They companies should become increasingly aware of the importance of motivating employees and should provide motivational practices that would help create OCB

\section{CONCLUSION}

The success of any organization is ultimately dependent on its Human Resources. The organization should therefore be able to inspire the human resources through exceptional motivational practices. This will definitely help the manufacturing companies to achieve high quality and productivity with less cost and will be instrumental in developing the economy of our country.

"We are all motivated by a keen desire for praise and the better a man is, the more he is inspired to glory"

-Thomas Jefferson.

\section{REFERENCES}

1. Shore, L. M., \& Martin, H. J. (1989).Job satisfaction and organizational commitment in relation to work performance and turnover intentions. Human Relations, 42(7), 625-638.

2. Denton, K. (1987). Effective Appraisals: Key to Employee Motivation. Industrial Engineering, 19(12), 24.

3. Hackett, R. D., Lapierre, L. M., \&Hausdorf, P. A. (2001). Understanding the links between work commitment constructs. Journal of Vocational Behavior, 58, 392-413.

4. Meyer, J. P., Allen, N. J. \& Smith, C.A. (1993). Commitment to Organizations and Occupations: Extension and Test of a Three-Component Conceptualization. Journal of Applied Psychology, 78(4), 538-552.

5. Bashaw, R.E., \& Grant, E.S. (1994).Exploring the distinctive nature of work commitments: Their relationships with personal characteristics, job performance, and propensity to leave. Journal of Personal Selling \& Sales Management, 14(2), 1-16.

6. Lawler, E.E. (1986). High involvement management: participative strategies for improving organizational performance. San Francisco: Jossey-Bass.

\section{AUTHORS PROFILE}

Dr. Lydia H Swamy Assistant Professor, Department of BBA, Nirmala College for Women.

\begin{tabular}{|l|l|c|c|}
\multicolumn{5}{|c|}{ Note } \\
\hline \multirow{2}{*}{ Table } & \multicolumn{3}{|c|}{ Table Column Head } \\
\cline { 2 - 4 } & Table column subhead & Subhead & Subhead \\
\hline copy & More table copy ${ }^{\mathrm{a}}$ & & \\
\hline \multicolumn{4}{|c|}{${ }^{\text {a. Sample of a Table footnote. (Table footnote) }}$}
\end{tabular}

The figure, graph, chart can be written as per given below schedule. 